\title{
FUZZY LOGIC APPLICATIONS IN INLAND WATERWAY TRANSPORTATION
}

\section{UPRAVLJANJE SAOBRAĆAJEM NA UNUTRAŠNJIM VODNIM PUTEVIMA PRIMENOM FUZZY LOGIKE}

\author{
Vladimir BUGARSKI, Filip KULIĆ, Željko KANOVIĆ, Todor BAČKALIĆ, \\ Faculty of Technical Sciences, University of Novi Sad, 21000 Novi Sad, Trg Dositeja Obradovića 6, Serbia \\ e-mail: bugarski@uns.ac.rs
}

\begin{abstract}
New applications of a fuzzy expert system (FES) for direct control of traffic lights in the areas of locks and one-way sections on inland waterways are presented. FES implements the knowledge of experts in the field of water transport on a controller. FES-SL (application in ship locks) was created for a single-chamber two-way ship lock. The system decides when the lock process will be performed depending on the current requests and queues. FES-1WS (application in one-way sections) was created for a canal network with sections where one-way vessel traffic is allowed due to the width limitation. The system is applicable for different traffic densities (from 10 to 90 vessels per day) and different lengths of one-way sections (from $2 \mathrm{~km}$ to $24 \mathrm{~km}$.
\end{abstract}

Keywords: traffic control, inland waterway, fuzzy expert system.

\section{REZIME}

Inteligentne infrastrukture $i$ „pametni semafori“ već neko vreme se koriste u drumskom saobraćaju. Međutim, upotreba računarske inteligencije u saobraćaju na unutrašnjim vodnim putevima još uvek je u povoju. Organizacija saobraćaja u zoni brodske prevodnice mora biti rezultat kompromisa između racionalnog korišćenja prevodnice (potrošnja vode, struje $i$ dr.) $i$ minimizacije vremena zadržavanja plovila koja čekaju na prevođenje. U ovom radu prikazan je novi metod upotrebe fazi logike za kreiranje fazi ekspertskog sistema (FES) koji se može koristiti kao sistem za podršku u odlučivanju ili kao „pametni“ upravljački sistem za direktno upravljanje semaforskom signalizacijom u zonama brodskih prevodnica i jednosmernih deonica na unutrašnjim vodnim putevima. FES-BP (primena kod brodskih prevodnica) kreiran je na modelu jednokomorne dvosmerne brodske prevodnice. Sistem odlučuje kada će prevođenje biti izvršseno u zavisnosti od trenutnih zahteva i redova čekanja. Predloženi sistem može se koristiti na više načina: kao deo upravljačkog sistema u automatskom ili poluautomatskom režimu rada; kao podrška u odlučivanju kod klasičnog operatorskog upravljanja prevodnicom ili kao platforma za obuku novih prevodničara. FES-JD (primena kod jednosmernih deonica) je kreiran za model kanalske mreže sa deonicama na kojima je zbog ograničenja širine dozvoljen jednosmerni saobraćaj plovila, u vidu naizmeničnog propuštanja plovila po smerovima. Ispitane su različite gustine saobraćaja od 10 do 90 plovila na dan i različite dužine jednosmernih deonica od $2 \mathrm{~km}$ do $24 \mathrm{~km}$. FES-JD se pokazao kao inteligentni sistem za upravljanje semaforskom signalizacijom.

Ključne reči: upravljanje saobraćajem, unutrašnji vodni putevi, semaforska signalizacija, fazi ekspertski sistem.

\section{INTRODUCTION}

Inland waterway traffic is one of the most important forms of traffic. The bottlenecks in terms of capacity are ship locks and one-way sections (Bugarski et al., 2012). On these segments of the waterway, it is necessary to control the traffic of the vessel and it is most often done with traffic light signalization. Intelligent infrastructures and "smart traffic lights" have been used in road traffic for some time. However, the use of computer intelligence in inland waterway transport is still in its infancy. The organization of traffic in the ship lock zone must be the result of a compromise between the rational use of the lock (consumption of water, electricity, etc.) and the minimization of time the vessels waiting for transfer, while in one-way sections the emphasis is on increasing section capacity (Bugarski, 2015).

\section{MATERIAL}

Fuzzy logic together with fuzzy set theory was first introduced in 1965 by professor Lotfi Zadeh. Later, it was upgraded with fuzzy reasoning and fuzzy inference systems. Fuzzy variables are fuzzified from crisp measured values using fuzzy membership function definitions. With fuzzy variables, it is possible to design fuzzy IF-THEN rules on an abstract level. New fuzzy variables, which are the implication part of the fuzzy rules, are then aggregated to a final fuzzy set and defuzzified. If a fuzzy inference system is designed with the use of expert knowledge, it becomes a Fuzzy Expert System (FES). Experts are here to assist in definitions for rules and membership functions. Recent extensive applications of fuzzy logic in expert systems and decision support systems are attested in broad literature (Aghamohagheghi et al., 2021; Jana and Pal, 2021; Okfalisa et al., 2021).

A new method of using fuzzy logic to create a fuzzy expert system (FES) that can be used as a decision support system or as a "smart" control system for direct control of traffic lights in the areas of locks and one-way sections on inland waterways is presented in this paper. FES enables the knowledge of experts in the field of water transport (operator-dispatcher) to be implemented on a computer (controller). FES-SL (application in ship locks) was created for a single-chamber two-way ship lock. Figure 1 presents the representative ship lock "Kucura" on the Danube-Tisa-Danube hydro system. FES-SL decides when the lock process will be performed depending on the current requests and queues. 

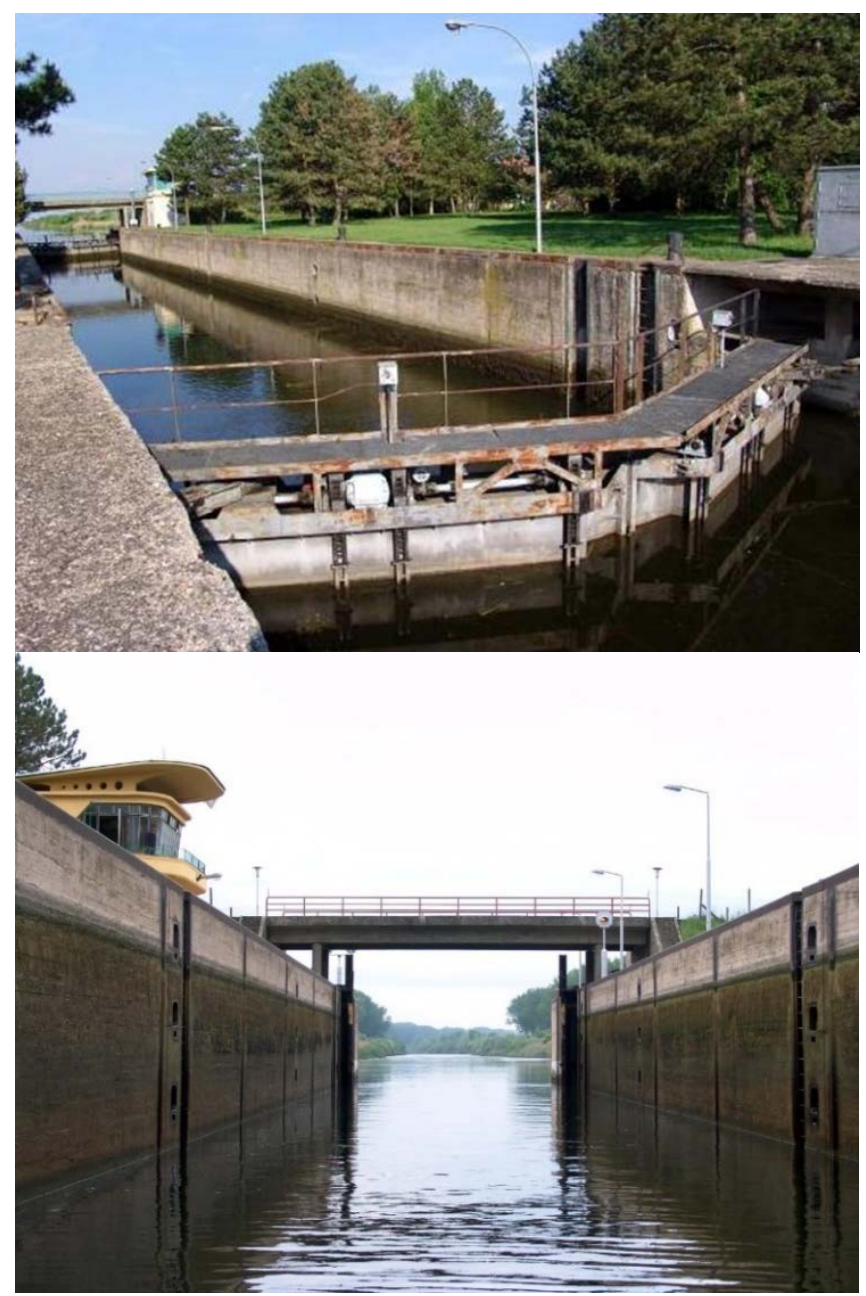

Fig. 1. Ship lock "Kucura”

A lock dilemma (Bačkalić et al., 2016) occurs in a situation presented in Figure 2. LC (Lock Condition) raises a question mark: which vessel should be served first? The vessel which is far from the ship lock and comes from the Level at which the Gate is Open (LGO) or the vessel, which is closer to the ship lock, but it is at the Level at which the Gate is currently Closed (LGC)?

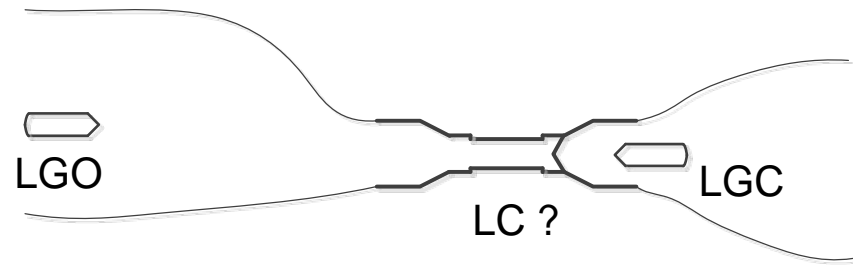

Fig. 2. Lock dilemma

FES-SL is designed to best address the dilemma problem with the fuzzy rules presented in Table 1 and fuzzy membership functions for fuzzy variables $L G O, L G C$ and $L C$ presented in Figures 3, 4 and 5, respectively. The control surface obtained with FES-SL is shown in Figure 6. FES-1WS (application in one-way sections) was created for a canal network with sections where one-way vessel traffic is allowed due to the width limitation, in the form of alternating passing of vessels from opposite directions. The basic idea is to adjust the duration of the green light to the current traffic density. The goal is to increase the capacity of the restricted section, i.e., to minimize the waiting time of the vessel at the entrance to the one-way section.
Table 1. FES-SL fuzzy rules (Bugarski et al., 2013)

\begin{tabular}{|c|c|c|c|}
\hline \multirow{2}{*}{ LGO } & LGC & \multicolumn{2}{|c|}{ Large } \\
\cline { 2 - 4 } & Small & Medium & No change \\
\hline Small & No change & No change & No change \\
\hline Medium & Indefinite & No change & No change \\
\hline Large & Change & Indefinite & No \\
\hline
\end{tabular}

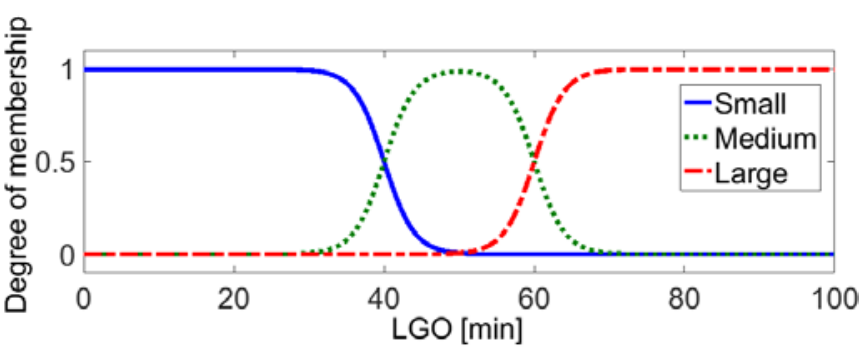

Fig. 3. Membership functions for input variable $L G O$ (Level where the Gate is Open)

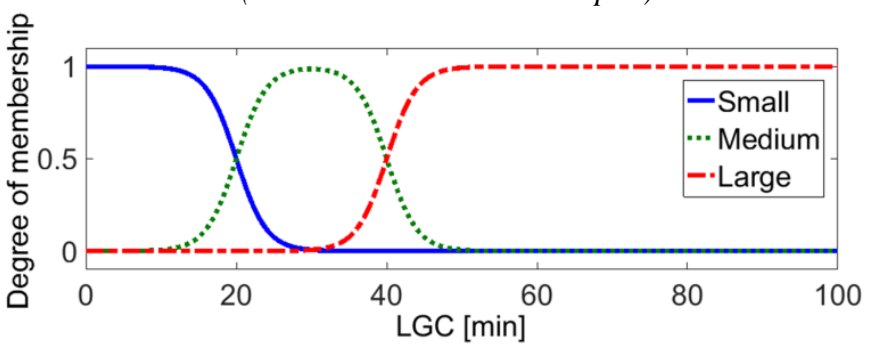

Fig. 4. Membership functions for input variable $L G C$ (Level where the Gate is Closed)

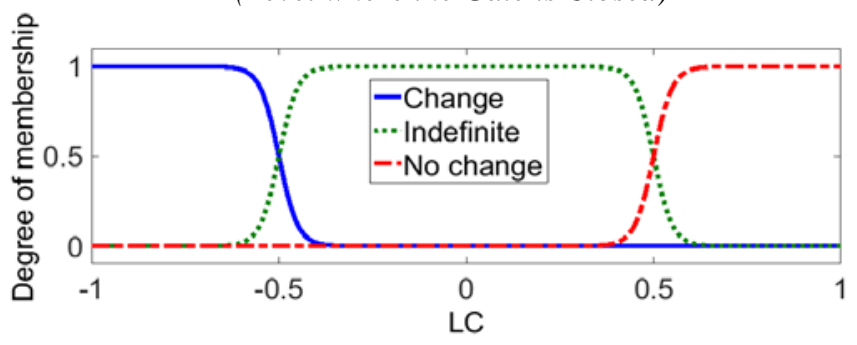

Fig. 5. Membership functions for output variable $L C$ (Lock Condition)

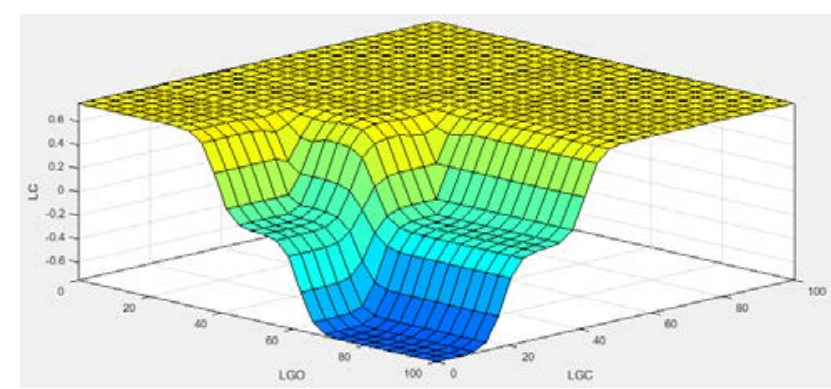

Fig. 6. The control surface of FES-SL

The system is applicable for different traffic densities (from 10 to 90 vessels per day) and different lengths of one-way sections (from $2 \mathrm{~km}$ to $24 \mathrm{~km}$ ).FES is designed with four input variables: number of vessels upstream/downstream (observed interval $-24 \mathrm{~km}$ in both directions) and arrival time of the last vessel upstream/downstream (observed period -3 hours in both directions). The output variable is the result of the 81 fuzzy rules in total: duration of green light for a certain direction. Membership functions of the output fuzzy variable are presented in Figure 7. The allowed range is from 0 to 240 minutes where positive values are denoted to the duration of green light upstream, and negative values - downstream. One view of fuzzy rules is presented in Figure 8. 


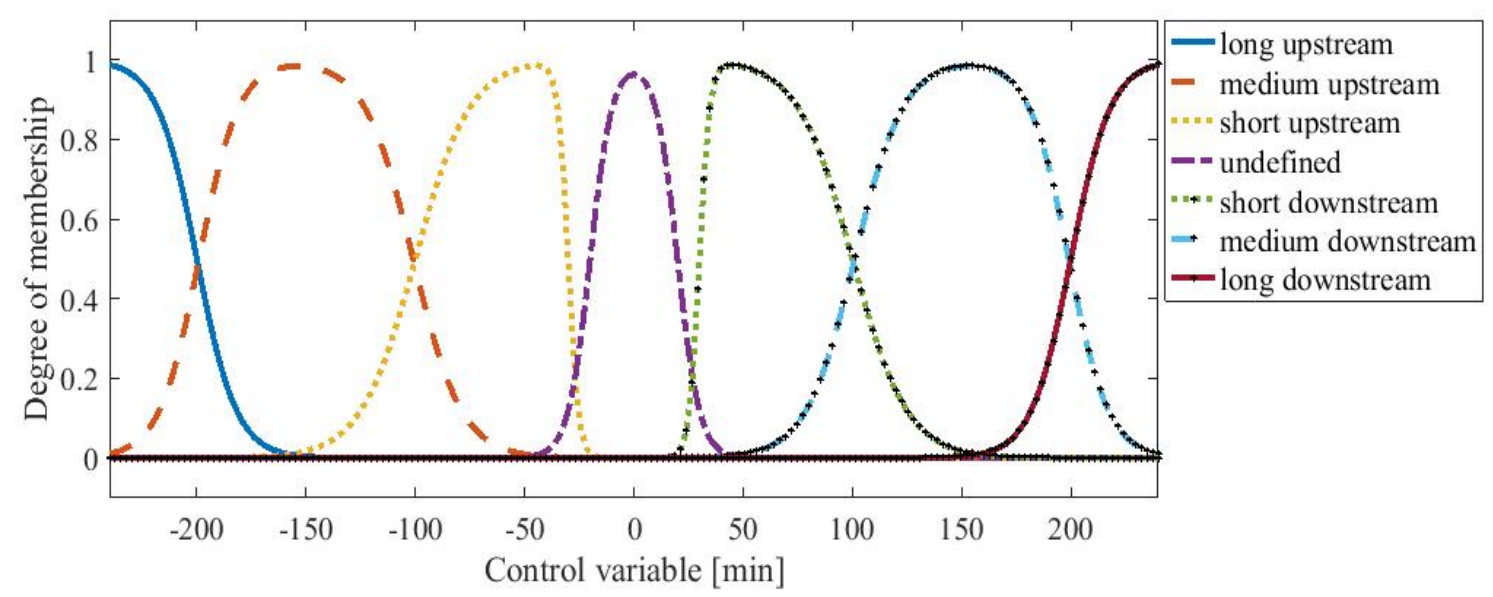

Fig. 7. Output control variable: duration of green light

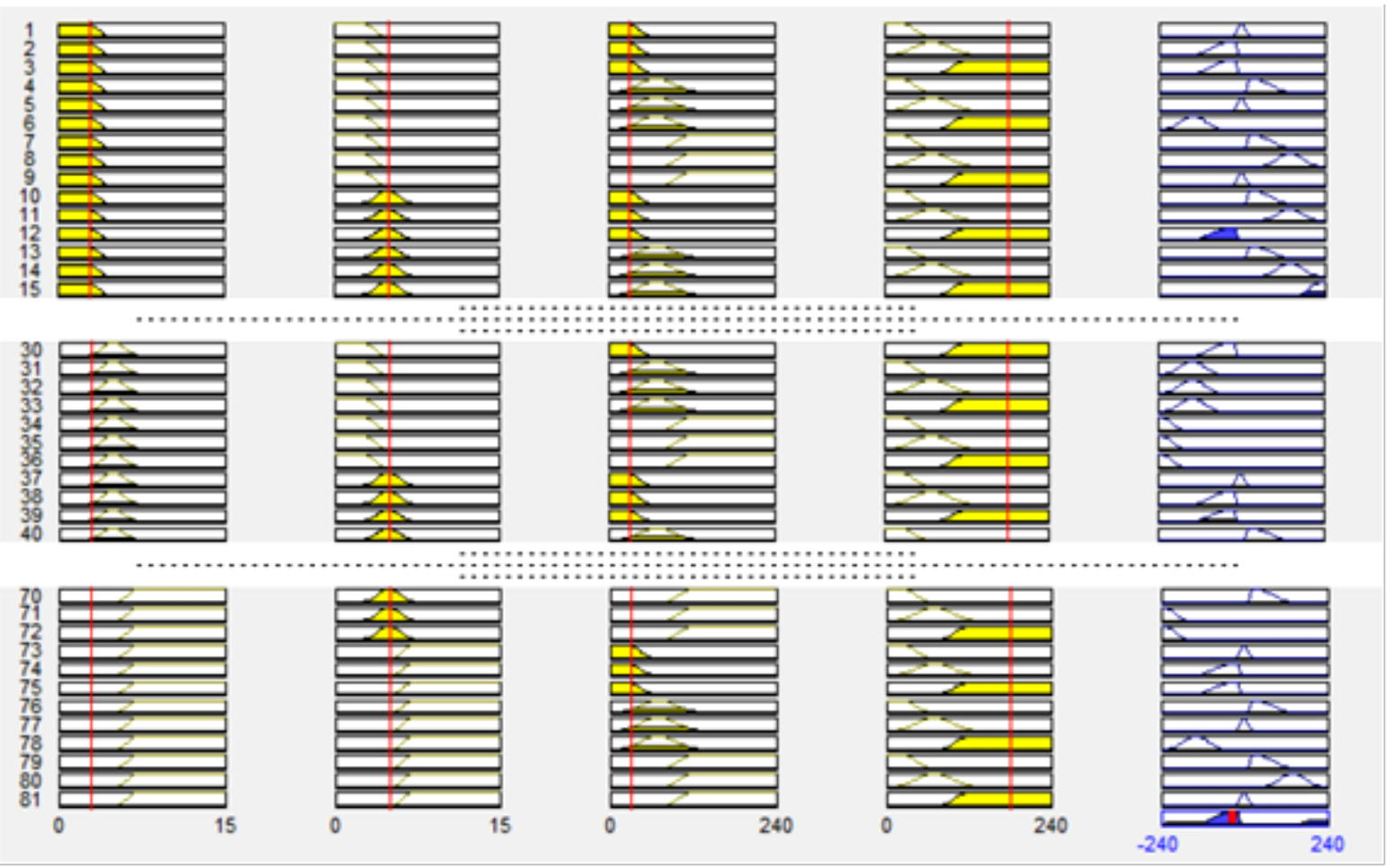

Fig. 8. FES-1WS fuzzy rule view (Bugarski et al., 2019)

\section{DISCUSSION}

Ship locks and one-way sections are bottlenecks in the throughput capacity of navigable canals. When a vessel arrives at a bottleneck, decisions need to be made that will lead finally to a control action. Decisions are mostly human judgment and evaluation, and are not based on precise input data, but rather are unclear, fuzzily, blurred, and imprecise (Kanović et al., 2019).

The problem is how to transfer the decision-making process from human to machine. How to transfer the imprecise and estimated work descriptions of some system into the computer by simple rules? Proposed solution: fuzzy set theory + fuzzy logic reasoning + knowledge of the expert-operator + fuzzification and defuzzification = FES (fuzzy expert system).

Interviewing the operators gives the insight view of decisions like how to know when to change the lock condition (perform an empty lockage). They will do it if the vessel from the closed side of the lock is near and the vessel from the open side of the lock is far away. What do the terms "near" or "far away" mean in computer language? If the vessel is to arrive at the lock zone within the next 20 minutes it is "near", but if it needs more than one hour, it is "far away". That is how fuzzy variables are created and defined. If the vessel is "near" to the lock zone, the distance is called small and if the vessel is "far away" from the lock, the distance is called large. Distance is calculated in minutes. Calculations are based on the position and the speed of the vessel which is obtained through the river information service. Some efforts are made in trying to optimize the membership functions of fuzzy expert systems and results are presented in (Kanović et al., 2014a; Kanović et al., 2014b)

In controlling traffic on one-way sections of a navigable canal, various simulation experiments are performed. Different traffic densities are simulated: 10, 25, 50 and 80 vessels/day from both sides (even distribution) and uneven distributions with 10 vessels/day from one side and 25, 50 and 90 from the other side. Figure 9 shows simulation results of an experiment with uneven distribution of 10 vessels/day downstream and 90 vessels/day upstream, on an $8 \mathrm{~km}$ one-way section of a navigable canal. 


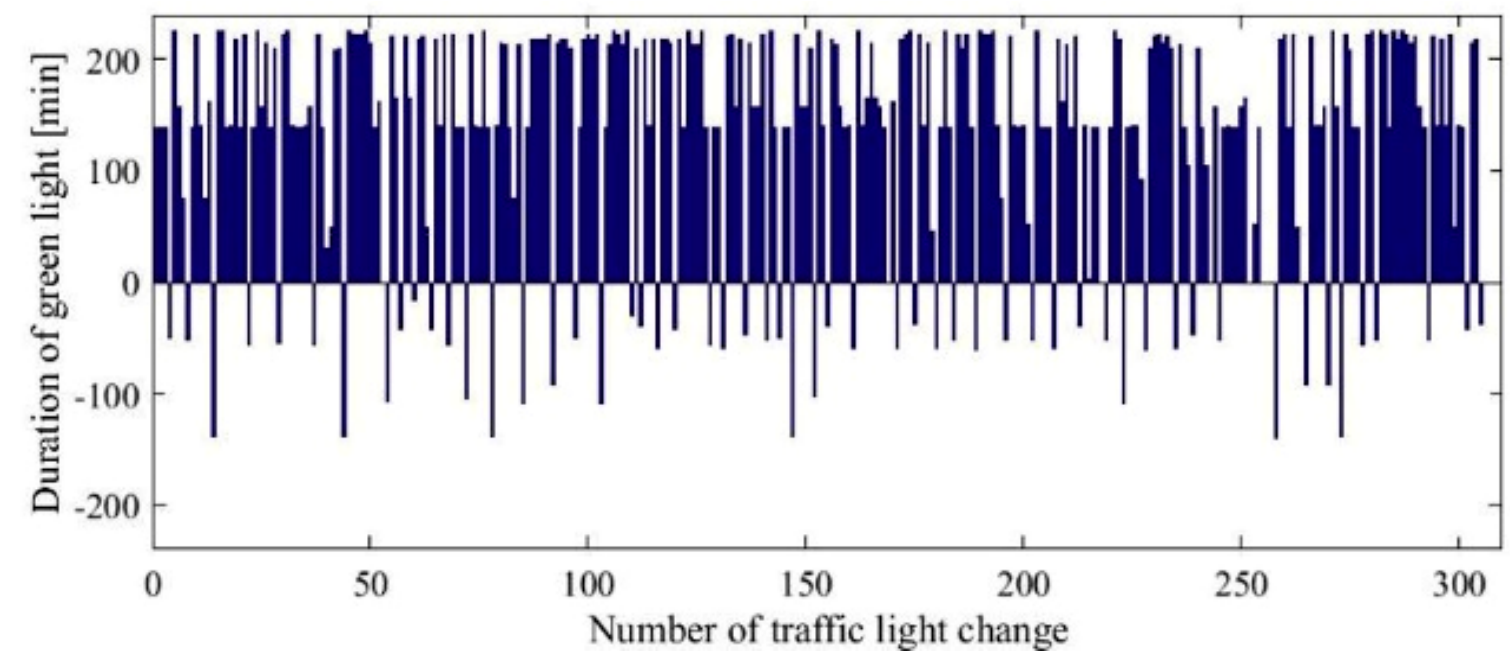

Fig. 9. FES-1WS simulation results for traffic density of 10/90 vessels per day downstream/upstream

\section{CONCLUSION}

Two applications of fuzzy expert systems are presented for traffic control on inland waterways. The first one (FES-SL) is designed for control of ship lock gates. The system can be used in several ways: as part of the control system in automatic or semi-automatic mode; as decision support in classic manual operator control or as a platform for training new operators. FES-SL can be optimized to reduce the number of empty lockages and the average waiting time per vessel. Further development and research may include greater complexity in lock functionality, multi-channel locks, multi-chamber locks, a variety of water level differences and vessel dimensions. Different priorities need more complex fuzzy variables and rules.

The second one (FSE-1WS) is designed for the control of traffic lights on one-way sections of navigable canals. Significant improvements have been shown compared to the classic traffic light control with a fixed duration of green and red lights.

ACKNOWLEDGMENT: This paper is a result of the research within the projects TR31058 and TR33013, both supported by the Ministry of Education, Science and Technology, Republic of Serbia.

\section{REFERENCES}

Aghamohagheghi, M., Hashemi, S., Tavakkoli-Moghaddam, R. (2021). An advanced decision support framework to assess sustainable transport projects using a new uncertainty modeling tool: Interval-valued Pythagorean trapezoidal fuzzy numbers. Iranian Journal of Fuzzy Systems, 18 (1), 53-73.

Bačkalić, T., Bugarski, V., Kulić, F., Kanović, Ž. (2016). Adaptable Fuzzy Expert System for Ship Lock Control Support. Journal of Navigation, 69 (6), 1341-1356.

Bugarski, V., Matić, D., Nikolić, P., Kamenko, I. (2012). Controlling ship lock with a fuzzy expert system. Journal on
Processing and Energy in Agriculture (former PTEP), 16 (4), 162-164.

Bugarski, V., Bačkalić, T., Kuzmanov, U. (2013). Fuzzy decision support system for ship lock control. Expert Systems with Applications, 40 (10), 3953-3960.

Bugarski, V. (2015). Ekspertski sistem za upravljanje brodskom prevodnicom zasnovan na računarskoj inteligenciji. Doktorska disertacija. Fakultet tehničkih nauka, Univerzitet u Novom Sadu, Srbija.

Bugarski, V., Bačkalić, T., Kanović, Ž., Kulić, F., Zeković, M. (2019). Fuzzy expert system for adaptive vessel traffic control on a one-way section on a navigable canal. Scientific Journal Transport Problems, 14 (4), 39-50.

Jana, C., Pal, M. (2021). Extended bipolar fuzzy EDAS approach for the multi-criteria group decision-making process. Computational and Applied Mathematics, 40 (9).

Kanović, Ž., Bugarski, V., Bačkalić, T. (2014a). Ship Lock Control System Optimization using GA, PSO and ABC: A Comparative Review. PROMET - Traffic\&Transportation, 26 (1), 23-31.

Kanović, Ž., Bugarski, V., Bačkalić, T., Jeličić, Z., Petković, Milena, Matić, D. (2014b). Optimization of ship lock control system using swarm-based techniques. Journal on Processing and Energy in Agriculture (former PTEP), 18 (1), 30-35.

Kanović, Ž., Bugarski, V., Bačkalić, T., Kulić, F. (2019). Application of Nature-Inspired Optimization Techniques in Vessel Traffic Control. Chapter in Shandilya, Shishir Kumar, Shandilya, Smita, Nagar, Atulya K (Eds.). "Advances in Nature-Inspired Computing and Applications”, Springer, 223252.

Okfalisa, Okfalisa, Rusnedy, Hidayati Iswavigra, Dwi Utari, Pranggono, B., Haerani, Elin, Saktioto, T. (2021). Decision support system for smartphone recommendation: The comparison of fuzzy AHP and fuzzy ANP in multi-attribute decision making. SINERGI, 25 (1), 101-110.

Received: 11. 01. 2021.

Accepted: 10. 02. 2021. 